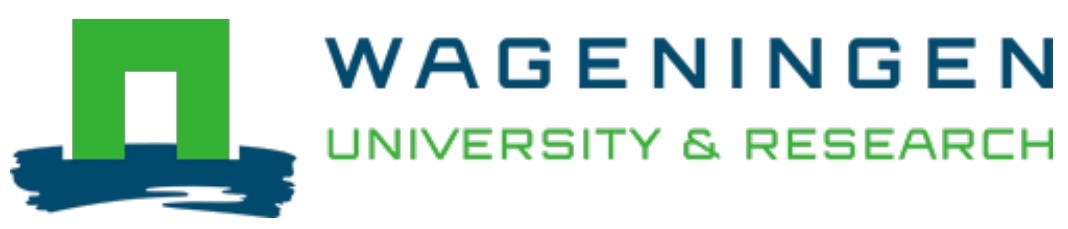

\title{
Groene dagbesteding in de stad: een levendige plek voor mensen met dementie
}

Mens \& Maatschappij

Bruin, Simone; Buist, Yvette; Hassink, Jan; Vaandrager, Lenneke

https://doi.org/10.5117/MEM2020.2.005.DEBR

This publication is made publicly available in the institutional repository of Wageningen University and Research, under the terms of article $25 \mathrm{fa}$ of the Dutch Copyright Act, also known as the Amendment Taverne. This has been done with explicit consent by the author.

Article $25 \mathrm{fa}$ states that the author of a short scientific work funded either wholly or partially by Dutch public funds is entitled to make that work publicly available for no consideration following a reasonable period of time after the work was first published, provided that clear reference is made to the source of the first publication of the work.

This publication is distributed under The Association of Universities in the Netherlands (VSNU) 'Article $25 \mathrm{fa}$ implementation' project. In this project research outputs of researchers employed by Dutch Universities that comply with the legal requirements of Article $25 \mathrm{fa}$ of the Dutch Copyright Act are distributed online and free of cost or other barriers in institutional repositories. Research outputs are distributed six months after their first online publication in the original published version and with proper attribution to the source of the original publication.

You are permitted to download and use the publication for personal purposes. All rights remain with the author(s) and / or copyright owner(s) of this work. Any use of the publication or parts of it other than authorised under article $25 \mathrm{fa}$ of the Dutch Copyright act is prohibited. Wageningen University \& Research and the author(s) of this publication shall not be held responsible or liable for any damages resulting from your (re)use of this publication.

For questions regarding the public availability of this publication please contact openscience.library@wur.nl 


\title{
In de etalage
}

\section{Groene dagbesteding in de stad: een levendige plek voor mensen met dementie}

\author{
Simone de Bruin, Yvette Buist, Jan Hassink en Lenneke Vaandrager
}

Oorspronkelijk artikel: De Bruin SR, Buist Y, Hassink J, Vaandrager L (2019). 'I want to make myself
useful': the value of nature-based adult day services in urban areas for people with dementia and
their family carers, Ageing \& Society, doi:10.1017/So144686X19001168.

In de afgelopen jaren is er veel ervaring opgedaan met dagbesteding op zorgboerderijen voor mensen met dementie. Uit diverse onderzoeken blijkt dat zorgboerderijen gewaardeerd worden door mensen met dementie en hun mantelzorgers. Ook zijn er aanwijzingen dat dagbesteding op zorgboerderijen positief bijdraagt aan hun gezondheid en welzijn. Zorgboerderijen zijn meestal gelegen in landelijke gebieden; in steden zien we vrijwel geen zorgboerderijen. Echter, in stedelijke gebieden wonen wel de meeste mensen met dementie. Geïnspireerd door het concept zorgboerderijen zien we momenteel steeds meer groene initiatieven voor dagbesteding in de stad ontstaan (in dit artikel verder aangeduid als 'groene dagbesteding in de stad').

Evenals op zorgboerderijen krijgen mensen met dementie bij deze vorm van dagbesteding een gestructureerde dag en/of activiteiten aangeboden waarbij buitenactiviteiten zoals tuinieren en dierverzorging centraal staan. Bij een klein aantal groene initiatieven voor dagbesteding in de stad komen, naast mensen met dementie, ook andere doelgroepen, zoals mensen met een verstandelijke beperking of met psychische problemen. Verschillende initiatieven hebben daarnaast een winkel, restaurant of een mogelijkheid voor buurtbewoners om gratis groenten en fruit op te halen. Ze zijn daarom veelal ook toegankelijk voor een breed publiek. Bijvoorbeeld voor buurtbewoners, kinderen van nabijgelegen scholen en dagjesmensen.

Omdat groene dagbesteding in de stad nog een relatief nieuwe vorm van dagbesteding is, is onderzoek op dit terrein nog schaars. Een vraag die 
onder andere leeft, is wat de waarde van deze vorm van dagbesteding is voor de gezondheid en welzijn van mensen met dementie. Het artikel in Ageing \& Society gaat in op deze vraag. Voor het onderzoek dat in dit artikel beschreven wordt, namen we semigestructureerde interviews af bij 21 mensen met dementie (in dit artikel ook aangeduid als 'deelnemers'), 18 mantelzorgers en 17 aanbieders van groene dagbesteding, verspreid over Nederland. In Nederland kunnen vijf vormen van groene dagbesteding in de stad onderscheiden worden: 1 . sociaal ondernemers die dagbesteding aanbieden in een groene omgeving (bijv. stadsboerderij, stadstuin, park); 2. verpleeghuizen die hun tuin openstellen voor dagbesteding voor thuiswonende mensen met dementie; 3. welzijnsorganisaties die naast reguliere dagbestedingsactiviteiten ook groene activiteiten (bijv. wandeling, bezoek kinder- of stadsboerderij, groene werkzaamheden) aanbieden; 4. wijkbewoners die, samen met andere partijen, dagbesteding bieden in een buurttuin en 5 . mengvormen waarin een zorginstelling dagbesteding organiseert samen met andere partners (o.a. andere instellingen, burgers, sociaal ondernemers). We probeerden om respondenten van de vijf vormen van groene dagbesteding in het onderzoek te betrekken. Echter, ten tijde van het onderzoek kwam de vorm die wordt aangeboden door sociaal ondernemers het meeste voor. Respondenten van die vorm van dagbesteding zijn daarom wat oververtegenwoordigd in het onderzoek.

\section{Wat hebben we gevonden?}

De resultaten laten zien dat mensen met dementie, mantelzorgers en aanbieders van groene dagbesteding een diversiteit aan waarden (voor mensen met dementie) toekennen aan groene dagbesteding in de stad. Deze vorm van dagbesteding kan daarom op verschillende manieren bijdragen aan hun gezondheid en het welzijn.

Allereerst hebben mensen met dementie door de groene dagbesteding contact met natuur en dieren. Bij de groene dagbesteding zijn er bijvoorbeeld mogelijkheden om te wandelen, te ontspannen, buiten te zitten of te tuinieren. Op verschillende locaties zijn daarnaast dieren aanwezig die er ook voor zorgen dat deelnemers regelmatig buiten zijn.

Daarnaast is het op de groene dagbesteding mogelijk om actief te zijn en deel te nemen aan verschillende alledaagse activiteiten en werkzaamheden. Er is veelal een ruime keuze aan activiteiten waardoor deelnemers activiteiten kunnen doen die zij leuk vinden. Activiteiten worden afgestemd op hun voorkeuren en mogelijkheden. Aanbieders van groene dagbesteding weten goed wat hun deelnemers graag doen en daar spelen ze op in. De 
combinatie van de verschillende activiteiten en de buitenomgeving met verschillende plekken om naartoe te gaan (bijv. tuin, stal, boomgaard, werkplaats) zorgt er daarnaast voor dat deelnemers fysiek actief zijn. De respondenten geven aan dat het buiten zijn en het fysiek bezig zijn ertoe leiden dat deelnemers beter gaan eten. Ook het gezamenlijk bereiden en eten van de lunch stimuleert deelnemers om beter te eten.

Uit de interviews met de verschillende typen respondenten blijkt dat groene dagbesteding ook bijdraagt aan structuur in het leven van de deelnemers. Er is veelal een vaste dagindeling, met op vaste tijden activiteiten en koffie- en lunchmomenten. Elke dag zijn er activiteiten die gedaan moeten worden, zoals het verzorgen van dieren, het oogsten van kruiden en groenten voor de lunch, het bereiden van de lunch, etc. Ook zorgen de verschillende seizoenen en de gebeurtenissen die daarmee gepaard gaan voor structuur; dieren worden geboren, dieren groeien op, er moet gezaaid worden, er moet geoogst worden, etc.

Groene dagbesteding stimuleert ook sociale contacten, bijvoorbeeld onderling contact tussen deelnemers en contact met medewerkers van de groene dagbesteding. Voor diverse deelnemers zijn de sociale contacten het meest gewaardeerde aspect van de dagbesteding. Bij sommige locaties is er een winkel, een eetgelegenheid of kunnen vaste bezoekers wekelijks langs komen om groenten op te halen. Sommige locaties worden verder bezocht door kinderen van nabijgelegen scholen. Mantelzorgers en aanbieders van groene dagbesteding benoemen dat mensen met dementie door deze contacten midden in de maatschappij blijven en het gevoel krijgen 'erbij te horen'. Het ontmoeten van gelijkgestemden en het gemêleerde gezelschap doen deelnemers goed.

Ook het zinvol bezig kunnen zijn en iets kunnen betekenen worden als belangrijke waarden van groene dagbesteding gezien. Met name jongere deelnemers geven aan dat zij het belangrijk vinden dat ze echt zinvol werk kunnen doen. Sommige deelnemers hebben het gevoel dat ze gewoon aan het werk zijn op de dagbesteding. Deelnemers met kennis van tuinieren vinden het fijn om die kennis in te zetten en te delen. Hierbij wordt de focus op het 'gewone' leven gewaardeerd. Op de groene dagbesteding wordt weinig over zorg gesproken. Er is bovendien geen stigma; iedereen hoort erbij en iedereen is gelijkwaardig.

\section{Wat betekenen deze bevindingen voor praktijk en beleid?}

In beleidsvorming rondom zorg en ondersteuning voor mensen met dementie staan verschillende thema's centraal, waaronder een sociale benadering van dementie, persoonsgerichte zorg, mensen met dementie 
aanspreken op wat zij nog kunnen in plaats van alleen maar kijken naar hun ziekte, en het creëren van een dementievriendelijke samenleving. Ons onderzoek laat zien dat groene dagbesteding op een aantal van deze thema's inspeelt. Bij groene dagbesteding wordt bijvoorbeeld goed gekeken naar de wensen en mogelijkheden van mensen met dementie, en hoe zij hun dag zinvol kunnen invullen en een zinvolle bijdrage kunnen leveren. Daarnaast biedt groene dagbesteding mensen met dementie ook de mogelijkheid om contact te hebben met verschillende bezoekers van de groene dagbesteding, waardoor zij zich mogelijk onderdeel van de samenleving blijven voelen.

Hoewel ten tijde van ons onderzoek groene dagbesteding vooral door sociaal ondernemers werd aangeboden, is er wel groeipotentieel voor andere vormen van groene dagbesteding. Verschillende zorginstellingen hebben bijvoorbeeld toegang tot een tuin of tot groen rondom de instelling, dat zij (ook) kunnen gebruiken voor dagbesteding voor thuiswonende mensen met dementie. Eerder onderzoek heeft echter laten zien dat er voor zorginstellingen wel wat uitdagingen zijn om deze vorm van dagbesteding te bieden. Zo vergt het aanbieden van groene dagbesteding bijvoorbeeld niet alleen een geschikte fysieke omgeving, maar ook een faciliterende sociale en organisatorische omgeving. Hierbij kan bijvoorbeeld gedacht worden aan kennis van zorgbestuurders, managers en zorgprofessionals over zorginnovatie, commitment op verschillende organisatorische niveaus, aanpassingsvermogen en competente en creatieve zorgprofessionals. Echter, niet alle zorginstellingen voldoen aan deze randvoorwaarden. Als zorgbestuurders, managers en zorgprofessionals, in samenwerking met mantelzorgers en vrijwilligers, bereid zijn om in groen te investeren, dan hoeven deze uitdagingen groene innovaties niet in de weg te staan.

\section{Niet-gehuwde ouderen: zijn zij tegenwoordig sociaal beter af?}

\section{Theo van Tilburg en Bianca Suanet}

Vrije Universiteit Amsterdam

Van Tilburg, T.G., \& Suanet, B.A. (2019). Unmarried older people: Are they socially better off today? The Journals of Gerontology, Series B: Psychological Sciences and Social Sciences, 74, 14631473. http://dx.doi.org/10.1093/geronb/gby120

Niet-gehuwde oudere mensen zijn in veel opzichten in het nadeel ten opzichte van gehuwde ouderen. We weten uit eerder onderzoek dat 